\title{
Perancangan Prototip Perangkat Lunak Penerimaan dan Penelusuran Order di Industri Garmen
}

\author{
Agus Alim \\ Politeknik Piksi Ganesha Bandung \\ Jl. Jend.Gatot Subroto 301, Bandung \\ agusalim2010@gmail.com
}

\begin{abstract}
Abstrak- Era Revolusi Industri 4.0 telah merubah dunia industri menjadi lebih kompetitif. Penggunaan Teknologi Informasi menjadi keharusan untuk sukses menjadi salah satu kunci kesuksesan di dunia industri. Divisi marketing sebagai bagian vital di perusahaan memerlukan software untuk menerima order dan menelusuri order yang telah diterima untuk kepentingan manajemen perusahaan. Perancangan perangkat lunak ini telah dirancang untuk penerimaan dan penelusuran pesanan di industri khususnya industri garmen. Parameter Perangkat lunak ini meliputi konfigurasi Lead Time Pembeli, Target Bulanan, Pemeliharaan Data, serta setting konfigurasi (pengguna, divisi, tim dan pembeli). Data keluaran yang dihasilkan dalam simulasi ini adalah Kartu Penilaian Kinerja dan Laporan Penelusuran yang dilengkapi dengan indikator untuk memberikan peringatan kepada pihak manajemen untuk mengambil tindakan yang yang diperlukan.

Hasil pengujian terhadap prototip perangkat lunak telah memenuhi kriteria baik dari segi isi (sistem penerimaan dan penelusuran pesanan di industri garmen) maupun dari segi pemrograman (pembuatan perangkat lunak), yaitu kode program, sehingga dapat digunakan sebagai media pembelajaran.
\end{abstract}

Kata Kunci- marketing garment; penerimaan data pesanan; penelusuran pesanan.

Abstract-Industrial Revolution 4.0 era made indutries is more competitifeness. Information Technology is must be used to be successfull. Marketing division of industries as a vital part of the organization needs software as as tool for data entry and tracking order on the garment industry. There are parameters in this software i.e.: Buyer Lead Time, Monthly Target Configuration, Maintenance Data and Configuration Setting (user, division, team and buyer). The Data Output from this simulation are Performance Scorecard, Tracking Report, and provide features color arrangement to give an indication tool for management to take actions when it needs.

Based on the testing result, this design prototype has been full fill the content ( Entry Data and Tracking Order System on Garment Industry) criteria and also programming technology side i.e., program code, so these media can be used as a learning media.

Keywords: order data entry; garment marketing; tracking order

\section{PENDAHULUAN}

Kompetisi yang terjadi di dunia industri, khususnya industri garmen ekspor semakin ketat. Saat ini, banyak hal yang harus dilakukan oleh industri garmen agar dapat terus bersaing, salah satunya adalah penggunaan teknologi informasi, Beberapa kompetensi kunci yang diperlukan pada saat ini adalah kemampuan untuk mengumpulkan, menganalisis dan mengorganisasi data, mengkomunikasikan ide dan informasi, merencanakan dan mengorganisir kegiatan, menggunakan idea dan teknik matematika, bekerja sama dengan orang lain dalam suatu tim, mengatasi masalah, menggunakan teknologi dan pemahaman budaya.

Untuk memenuhi kebutuhan akan perangkat lunak tersebut, penulis memberanikan diri untuk membuat Perancangan Prototip Perangkat Lunak Penerimaan dan Penulusuran Order di Industri garmen, Salah satu fungsi bisnis yang sangat penting di industri garmen adalah sistem penerimaan dan penelusuran pesanan. Data pesanan yang diterima ini harus akurat dan dapat ditampilkan secara tepat waktu ke pihak manajemen industri garmen. Salah satu keluaran yang dihasilkan dari sistem ini adalah Laporan Penelusuran yang berguna untuk mengecek status dari pesanan yang diterima. Status pesanan dapat dikategorikan pesanan yang telah disetujui (apakah pembeli sudah memberikan persetujuan), pesanan yang sementara dikerjakan, atau di tunda karena alasan tertentu dari pembeli atau dari pihak manajemen perusahaan garmen atau statusnya dibatalkan. Dengan status yang cepat diketahui pihak manajemen perusahaan dapat dengan cepat mengambil tindakan untuk menghindari kerugian perusahaan seperti terjadinya kelambatan pengiriman barang ke pembeli yang dapat berdampak perusahaan kena denda atau kelebihan kapasitas produksi. 


\section{KAJIAN PUSTAKA}

\section{Pengertian Simulasi}

Pada umumnya, proses binis industri garmen dapat dibagi ke dalam empat tahapan besar, yaitu: persetujuan pesanan, produksi, administrasi, dan penjualan. Untuk pembuatan software ini perlu pengetahuan rekayasa perangkat lunak. Rekayasa Perangkat Lunak adalah ilmu pengetahuan yang menyatukan proses, metode, dan peralatan untuk mengembangkan sebuah perangkat lunak komputer. Pada saat ini dikenal dua pendekatan rekayasa perangkat lunak yaitu: pendekatan secara konvensional dan pendekatan yang berorientasi objek. Pada saat ini, pendekatan berorientasi objek banyak diimplementasikan dengan menggunakan Penyatuan Bahasa Permodelan (UML). UML adalah suatu bahasa (notasi dan aturannya) untuk memodelkan rancangan perangkat lunak dengan pendekatan berorientasi objek.

Sebuah model adalah deskripsi dari sesuatu. Model dapat dideskripsikan di dalam bentuk bahasa visual, di mana sebagian besar informasi model dinyatakan dengan simbol grafik dan hubunganhubungan. Model yang baik harus memiliki ciri-ciri akurat, konsisten, mudah dikomunikasikan dan dirubah, serta dapat dimengerti. Pembuatan model memerlukan bahasa permodelan. Bahasa Pemodelan yang beragam dapat di satukan dalam Penyatuan Bahasa Permodelan (UML). UML adalah bahasa pemodelan yang digunakan untuk mendeskripsikan suatu aktivitas. UML mempunyai kegunaan yang sangat luas. UML dapat digunakan untuk memodelkan proses bisnis, perangkat lunak di dalam segala tahapan pengembangan dan untuk semua tipe sistem, dan juga untuk memodelkan semua konstruksi yang mempunyai struktur statis dan sifat dinamis (Suhendar,A; Gunadi, Hariman, 2002).

Proses pengembangan perangkat lunak berbasis orientasi objek dimulai dengan tahapan-tahapan konsep dan prinsip-prinsip orientasi objek .

Tujuan dari analisis berorientasi objek adalah untuk memodelkan dunia nyata sehingga dapat dimengerti.

Langkah-langkah generik dari analisis berorientasi objek adalah sebagai berikut:

1. Penentuan persyaratan pelanggan

2. Identifikasi skenario atau use case.

3. Pembangunan suatu model persyaratan.

4. Pemilihan kelas dan objek

5. Pengidentifikasi atribut dan operasi

6. Penentuan struktur dan hirarki

7. Pembangunan suatu model hubungan objek

8. Pembangunan suatu model tingkah laku objek

9. Pengkajian model analisis orientasi objek terhadap skenario uses case.
Sudut pandang rekayasa perangkat lunak menekankan pada analisis berorientasi objek dan desain berorientasi objek serta memperhatikan pemrograman berorientasi objek sebagai hal yang penting tapi merupakan aktivitas sekunder yang merupakan hasil pertumbuhan dari analisis dan design. Pada saat kompleksitas sistem bertambah, arsitektur desain dari produk akhir berpengaruh kuat terhadap keberhasilannya daripada bahasa pemrograman yang telah digunakan.

Untuk tiap-tiap kelas dalam sebuah model, kode generator akan membuat sebuah "benda" (form, modul kelas, atau modul) yang bersesuain dengannya dalam project Visual Basic (Alam, J, Agus,M,1999). Hubungan (aggregation atau assosiasi) diterjemahkan ke dalam keanggotaan data, constant, property kelas atau variabel modul. Rational Rose juga membuat prosedur (prosedur fungsi atau prosedur property) untuk operasi (method) yang terdapat dalam kelas dalam model.

Kode yang dibangkitkan dari tiap-tiap elemen dalam model ditentukan oleh spesifikasi dari elemen-elemen tersebut dan model properties dari model tersebut. Rational Rose memiliki suatu cara tertentu (default) dalam memetakan tiap-tiap elemen model ke dalam kode (Suhendar, A; Gunadi, Hariman, 2002). Untuk menguji sistem berorientasi objek secara memadai, harus dilakukan tiga hal berikut:

1. Definisi pengujian harus diperluas untuk mencakup teknik penemuan kesalahan yang diaplikasikan ke model analisis berorientasi objek dan desain berorientasi objek.

2. Strategi untuk pengujian unit dan terintegrasi harus berubah secara signifikan.

3. Desain test case harus bertanggungjawab terhadap karakteristik unit perangkat lunak berorientasi objek.

Untuk mengintegrasikan data-data dalam sistem informasi ini dibutuhkan basis data yang menyediakan informasi bagi para pemakai. Basis data dibentuk dari sekumpulan file, file-file basis data yang akan dirancang dalam sistem ini

\section{METODE PENELITIAN}

Setelah melakukan analisa kebutuhan sistem yang akan dirancang, berikut ini adalah pemodelan terhadap kebutuhan sistem tersebut. Dalam perancangan sistem ini digunakan perangkat pemodelan sistem UML. Dengan memanfaatkan diagram use case akan digambarkan dialog yang 
dilakukan oleh aktor (entity di luar sistem yang memberikan/menerima masukan ke atau dari sistem) lewat fungsi-fungsi yang disediakan dalam sistem untuk mencapai suatu tujuan. Diagram use case menggambarkan fungsionalitas yang diharapkan dari sebuah sistem. Sebuah use case merepresentasikan sebuah interaksi antara aktor dengan sistem. Use case merupakan sebuah pekerjan tertentu, misalnya login ke sistem, memasukkan data dan sebagainya. Seorang aktor adalah sebuah entitas manusia atau mesin yang berinteraksi dengan sistem untuk melakukan pekerjaan-pekerjaan tertentu. Gambar 1, 2, 3, 4 dan 5 merupakan use case dari sistem ini.

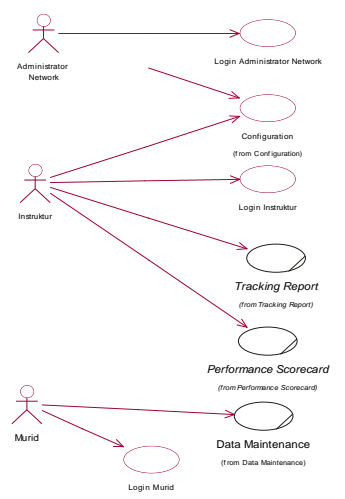

Gambar.1 Diagram use case Sistem Penerimaan Pesanan

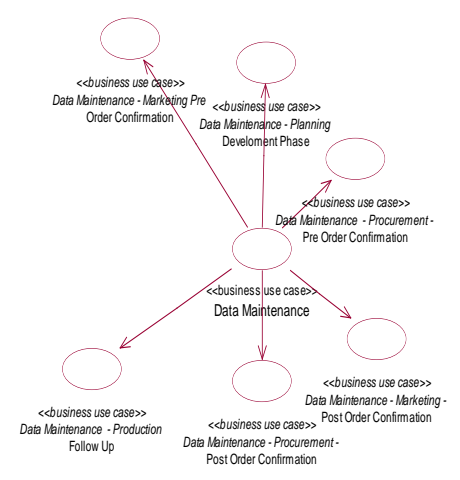

Gambar 2 Diagram use case paket pemeliharaan data

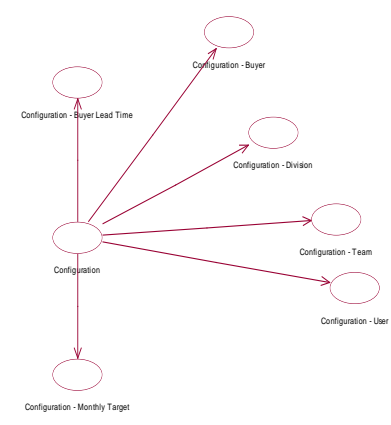

Gambar.3 Diagram use paket konfigurasi

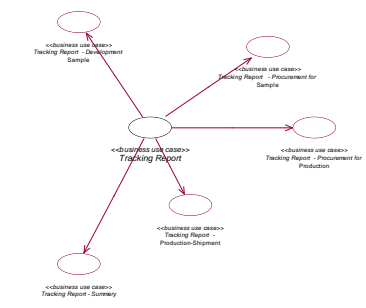

Gambar 4 Diagram use case paket laporan penelusuran

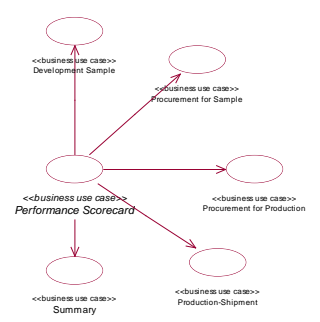

Gambar.5 Diagram use case paket kartu penilaian kinerja

\section{A. Analisa Sistem}

Pada intinya, analisa sistem adalah proses pemecahan sistem menjadi beberapa subsistem yang lingkupnya lebih kecil, dengan maksud agar lebih mudah dalam mengidentifikasi permasalahan, hambatan-hambatan, dan kesempatan-kesempatan yang ada dalam sistem, serta untuk mengetahui kebutuhan-kebutuhan sistem.

\section{B. Analisa Kebutuhan Sistem}

Aktivitas memasukkan data di divisi pemasaran dibagi menjadi beberapa fase pengerjaan yang dimulai dari Fase Pemasaran Sebelum Konfirmasi Pemesanan sampai ke Fase Produksi - Pengapalan.

\section{Analisis Perancangan Sistem}

Analisa kebutuhan sistem dilakukan untuk menguraikan masukan, proses, dan keluaran, menguraikan apa yang diperlukan oleh sistem informasi serta basis data, dan bagaimana yang akan dirancang untuk memenuhi kebutuhan.

Sistem penerimaan pesanan akan memenuhi kebutuhan-kebutuhan aktivitas di divisi pemasaran di industri garmen, yaitu:

1. Sistem harus harus menampilkan status dari masing-masing pemesanan dari pembeli. Tiaptiap pemesanan dari pembeli mempunyai tahapan yang berbeda-beda. 
2. Aspek penelusuran yaitu kemampuan untuk menampilkan pemesanan yang bermasalah berupa kelambatan dari atual dibandingkan dengan perencanaan maupun ketidaktepatan kuantitas aktual dibandingkan dengan kuantitas dari pesanan juga dimasukkan dalam perancangan perangkat lunak ini.

3. Perangkat lunak simulasi ini juga dirancang untuk menginginkan tahapan yang berubah sesuai dengan nama pembelinya, sehingga perancangan untuk konfigurasi jenisnya menjadi lebih rumit

4. Perancangan konfigurasi lead time untuk masingmasing jenis perlu dibuatkan lebih fleksibel dan lebih khusus untuk mengikuti dan mengakomodasi jenis masing-masing pesanan dari pembeli .

5. Keluaran hasil dari perangkat lunak ini berupa Laporan Penelusuran dan Kartu Penilaian Kinerja. Laporan Penelusuran menggambarkan tentang status dari pemesanan yang diterima yang harus ditampilkan perpesanan dan per-tim pemasaran dan perbagian dalam divisi pemasaran cukup menyulitkan, sedangkan Kartu Penilaian Kinerja melaporkan tentang kinerja dari masingmasing tim dan perbagian di divisi pemasaran yang harus dipilah-pilah perminggu, perbulan.

6. Perangkat lunak simulasi ini akan menyajikan proses bisnis untuk penjualan dan pemesanan pemasukan data di divisi pemasaran yang benarbenar data yang nyata dan dapat dipakai oleh perusahaan garmen.

7. Konfigurasi otoritas client dalam mengakses data dalam perangkat lunak ini, sehingga hanya yang mempunyai otoritas yang dapat mengaksesnya.

8. Format laporan yang ditampilkan untuk Laporan Penelusuran dan Kartu Penilaian Kinerja dalam bentuk yang mirip Excel Windows.

9. Pengaturan warna-warna untuk memberikan peringatan kepada pihak manajemen untuk mengambil tindakan yang yang diperlukan, yang dijelaskan sebagai berikut:

a) Laporan Penelusuran

Tabel 1. Indikasi warna Laporan Penelusuran

\begin{tabular}{|l|l|}
\hline Warna & Variansi \\
\hline Merah & Positif \\
\hline Hijau & Negatif \\
\hline
\end{tabular}

Keterangan: Nilai Variansinya yaitu $=$ Nilai Aktual - Nilai Plannya b) Kartu Penilaian Kinerja

Tabel 2 . Indikasi warna Kartu Penilaian Kinerja

\begin{tabular}{|c|l|}
\hline Warna & $\begin{array}{l}\text { Persentase } \\
\text { pencapaian (\%) }\end{array}$ \\
\hline Merah & Lebih kecil 60 \\
\hline Kuning & $\begin{array}{l}\text { Antara 60 } \\
\text { sampai dengan } \\
80\end{array}$ \\
\hline Hijau & Lebih besar 80 \\
\hline
\end{tabular}

Keterangan: Persentase pencapaian $(\%)=$

Nilai Aktual / Nilai target

\section{Mengidentifikasi Skenario atau Use Case}

Kebutuhan pengguna dapat dibuat spesifikasi use case yang dipakai untuk pembuatan diagram use case. Spesifikasi-spesifikasi use-case yang digunakan di dalam sistem simulasi penerimaan pesanan ini adalah Diagram Kelas; Diagram Objek; Diagram Keadaan; Diagram Urutan; Diagram Kolaborasi; Diagram Aktifitas; Diagram Komponen serta Diagram Penjabaran

Diagram kelas menggambarkan struktur dan deskripsi kelas, paket, dan objek beserta hubungan satu sama lain, seperti containment, pewarisan, asosiasi, dan lain-lain.

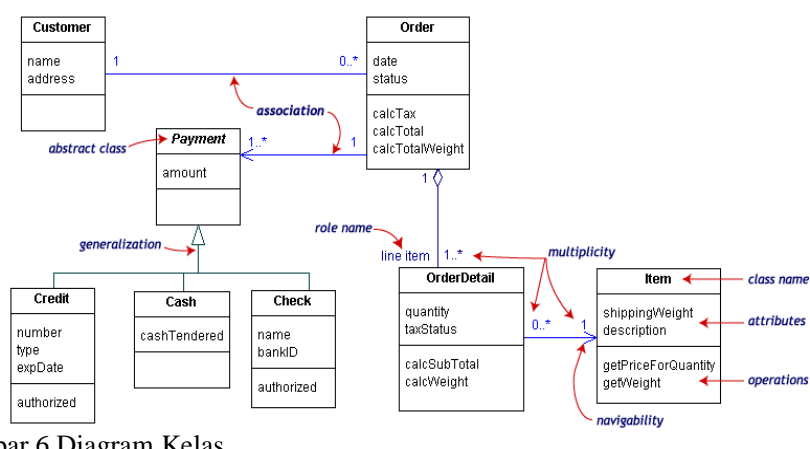

Gambar 6 Diagram Kelas

Diagram objek menunjukkan sejumlah objek kejadian kelas, dibandingkan dengan kelas aktual. Sebuah diagram objek adalah sebuah contoh dari diagram kelas yang menunjukkan sebuah kemungkinan dari eksekusi dari sistem.

Diagram keadaan (state diagram) adalah lawan dari deskripsi kelas. Ia memperlihatkan semua keadaan yang mungkin dimiliki oleh objek kelas, dan kejadian apa saja yang menyebabkan keadaan berubah. Suatu kejadian mungkin adalah objek lain yang 
mengirimkan pesan kepadanya sebagai contoh, waktu tertentu yang saling bertindihan- atau beberapa kondisi telah dipenuhi. Perubahan suatu keadaan disebut transisi. Transisi dapat juga mempunyai suatu aksi yang berhubungan dengannya yang mengspesifikasikan apa yang harus dilakukan dalam koneksi dengan transisi keadaan.

Diagram Urutan (sequence diagram) menggambarkan interaksi antar objek di dalam dan di sekitar sistem (termasuk pengguna, tampilan, dan sebagainya) berupa pesan yang digambarkan terhadap waktu. Diagram Urutan terdiri atar dimensi vertikal (waktu) dan dimensi horisontal (objek-objek yang terkait) (Eriksson, Hans-Erik and Penker, Magnus, 1998) .

Diagram urutan biasa digunakan untuk menggambarkan skenario atau rangkaian langkahlangkah yang dilakukan sebagai respons dari sebuah peristiwa untuk menghasilkan keluaran tertentu. Diawali dari apa yang memicu aktivitas tersebut, proses dan perubahan apa saja yang terjadi secara internal dan apa keluaran yang dihasilkan. Masingmasing objek, termasuk aktor, memiliki garis edar vertikal.

Pesan digambarkan sebagai garis berpanah dari satu objek ke objek lainnya. Pada fase desain berikutnya, pesan akan dipetakan menjadi operasi/metoda dari kelas.

Bar pengaktivan menunjukkan lamanya eksekusi sebuah proses, biasanya diawali dengan diterimanya sebuah pesan. Untuk objek-objek yang memiliki sifat khusus, standar UML mendefinisikan icon khusus untuk batas objek, pengendali dan persistent entity (Roff,T.,Jason, 2003).

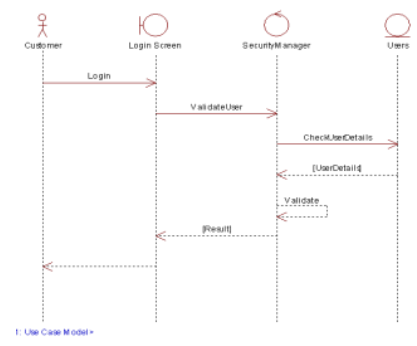

Gambar 7 Diagram Urutan

\subsubsection{Diagram Kolaborasi}

Diagram kolaborasi (collaboration diagram) juga menggambarkan interaksi antar objek seperti diagram urutan, tetapi lebih menekankan pada peran masingmasing objek dan bukan pada waktu penyampaian pesan.
Setiap pesan memiliki urutan nomor, di mana pesan dari level tertinggi memiliki nomor 1 . Pesan dari tingkatan yang sama memiliki awalan yang sama.

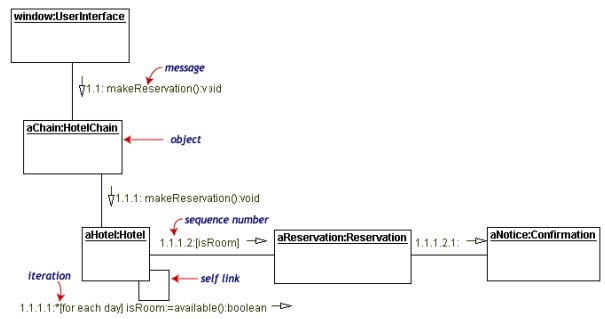

Gambar 8 Diagram Kolaborasi

Diagram aktivitas menggambarkan berbagai alir aktivitas dalam sistem yang sedang dirancang, bagaimana masing-masing alir berawal, keputusan yang mungkin terjadi, dan bagaimana mereka berakhir. Diagram aktivitas juga dapat menggambarkan proses sejajar yang mungkin terjadi pada beberapa eksekusi.

Sebuah aktivitas dapat direalisasikan oleh satu use case atau lebih. Aktivitas menggambarkan proses yang berjalan, sementara use case menggambarkan bagaimana aktor menggunakan sistem untuk melakukan aktivitas.

Diagram komponen menggambarkan struktur dan hubungan antar komponen piranti lunak, termasuk ketergantungan diantaranya.

Komponen piranti lunak adalah modul berisi kode, baik berisi source kode maupun kode biner, baik library maupun executable, baik yang muncul pada compile time, link time, maupun run time. Umumnya komponen terbentuk dari beberapa kelas dan/atau paket, tapi dapat juga dari komponenkomponen yang lebih kecil.

Diagram Penjabaran menggambarkan detail bagaimana komponen di-deploy dalam infrastruktur sistem, di mana komponen akan terletak (pada mesin, server atau piranti keras apa), bagaimana kemampuan jaringan pada lokasi tersebut, spesifikasi server, dan hal-hal lain yang bersifat fisikal

\section{HASIL DAN PEMBAHASAN}

Implementasi Sistem 


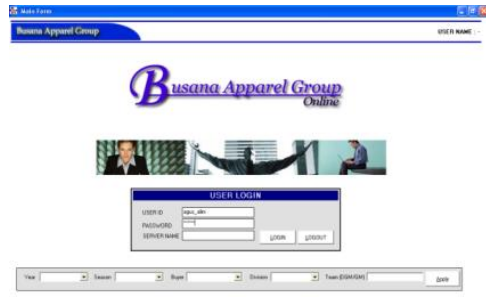

Gambar 9. Tampilan awal waktu pertama kali login
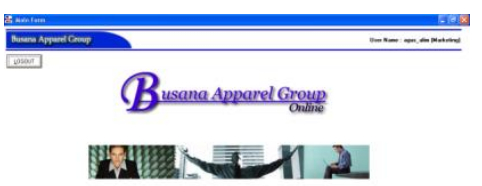

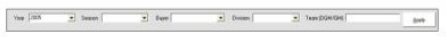

Gambar 10. Tampilan setelah pengguna memasukkan Pengguna ID dan password

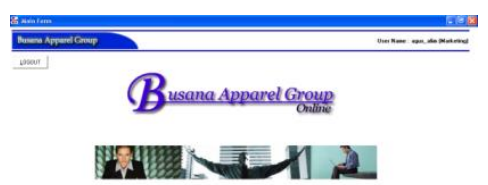

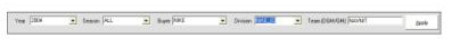

Gambar 11. Tampilan pada saat pengguna memasukkan data untuk proses filter

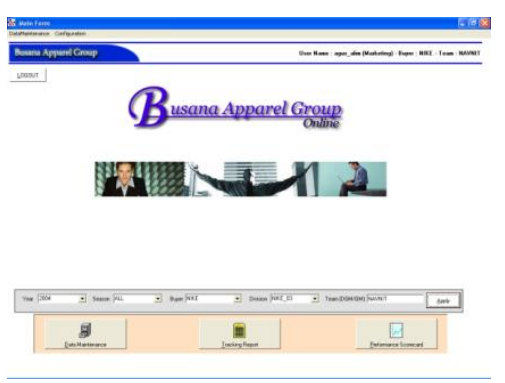

Gambar 12. Tampilan pada sistem melakukan proses filter

\subsubsection{Data Pemeliharaan}

\section{A. Pemasaran Sebelum Konfirmasi Pemesanan}

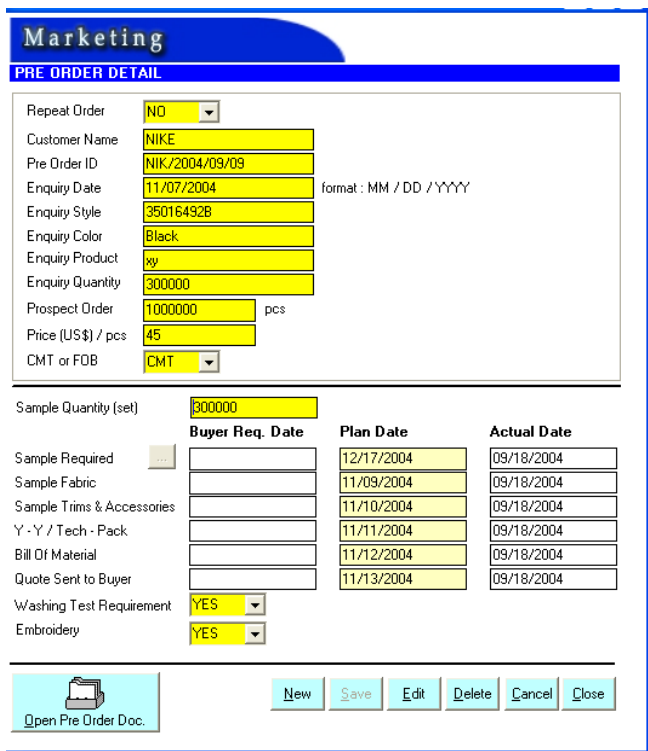

Gambar 13. Tampilan Data Pemeliharaan Pemasaran Sebelum Konfirmasi Pemesanan

\section{B. Fase Pengembangan Perencanaan}

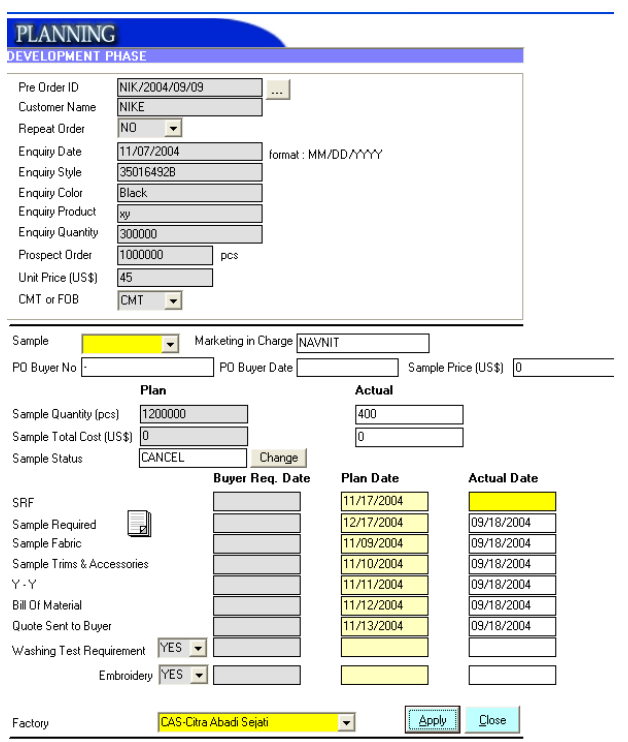

Gambar 14. Tampilan Data Pemeliharaan - Fase Pengembangan Perencanaan
C. Pengadaan Barang
Sebelum Konfirmasi
Pemesanan 


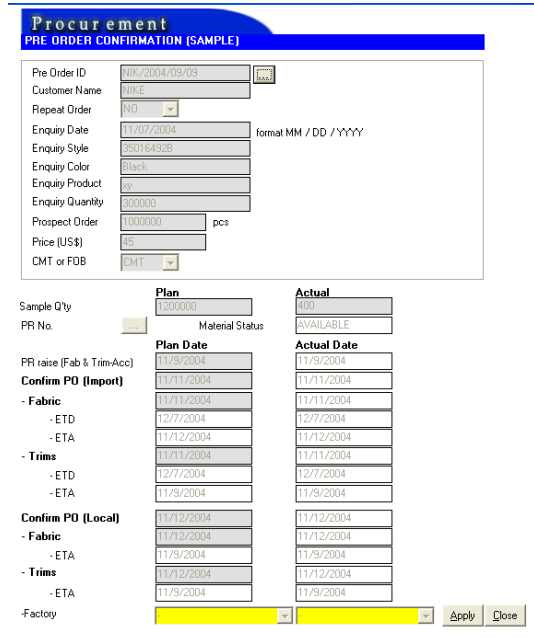

Gambar 15.Tampilan Data Pemeliharaan -

Pengadaan Barang Sebelum Konfirmasi Pemesanan

\section{Pemasaran Sesudah Konfirmasi Pemesanan}

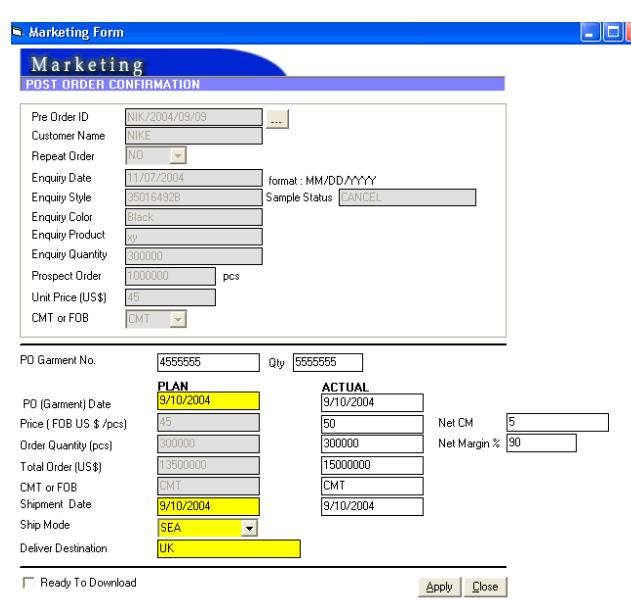

Gambar 16. Tampilan Data Pemeliharaan Pemasaran Sesudah Konfirmasi Pemesanan

\section{E. Pengadaan Barang Sesudah Konfirmasi Pemesanan}

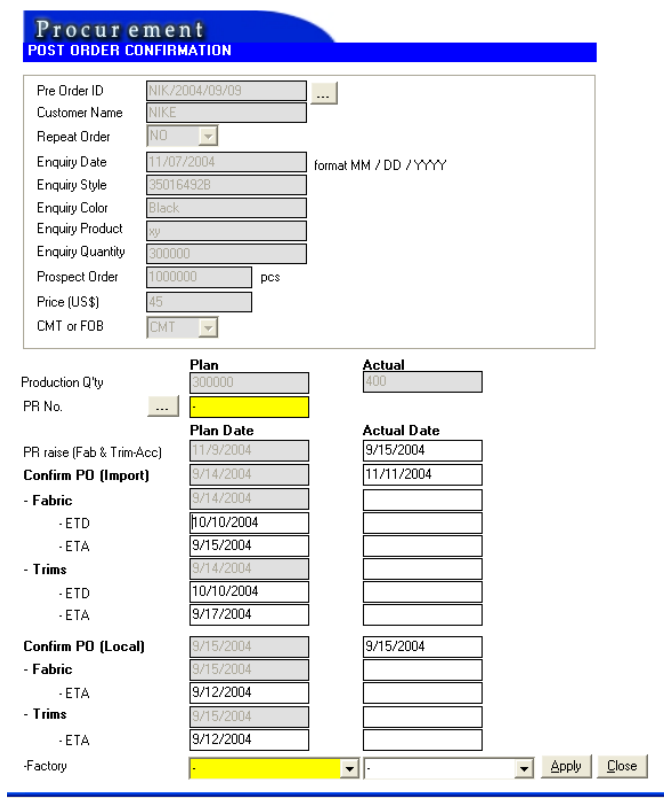

Gambar 17. Tampilan Data Pemeliharaan -Pengadaan Barang Sesudah Pemesanan Konfirmasi

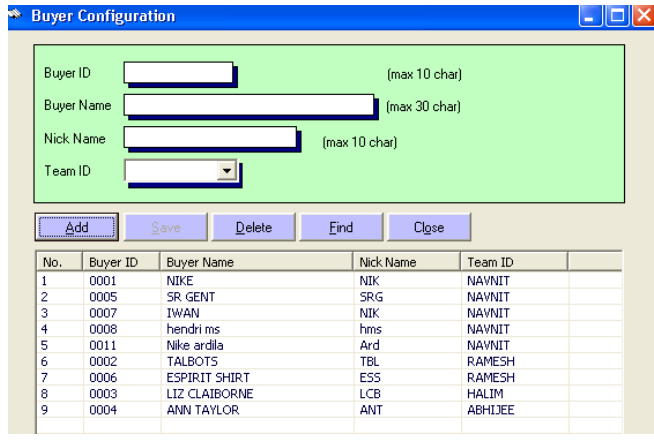

Gambar 20. Tampilan Konfigurasi - Pembeli

\section{F. Divisi}

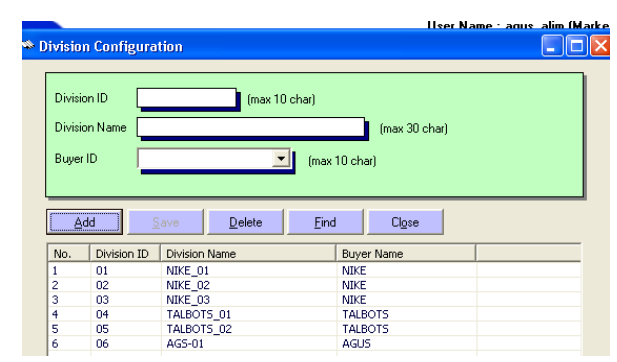

Gambar 21. Tampilan Konfigurasi - Divisi 
G. Tim

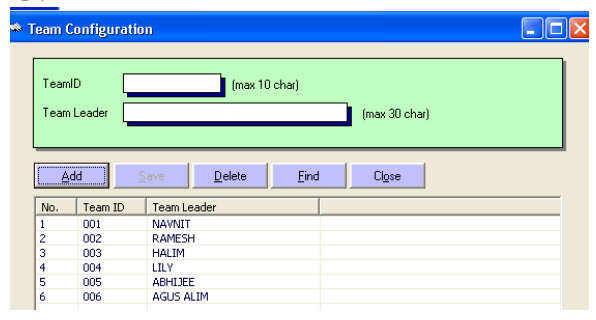

Gambar 22. Tampilan Konfigurasi - Tim

\section{H. Pengguna}

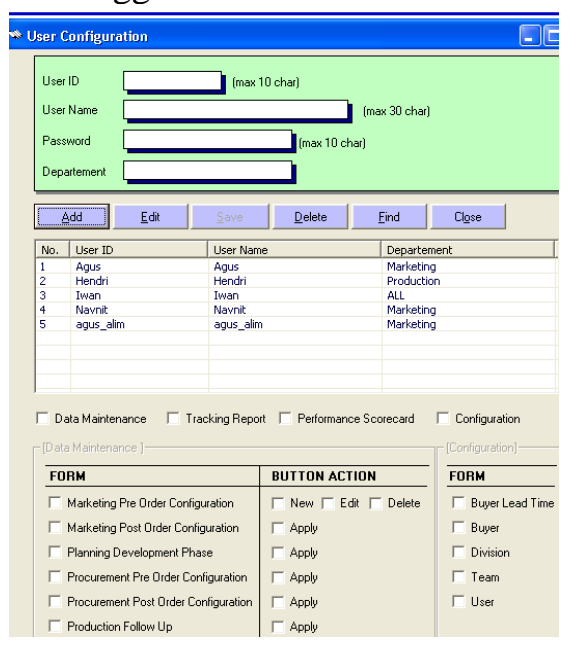

Gambar 23. Tampilan Konfigurasi - Pengguna

\section{I.Target Bulanan}

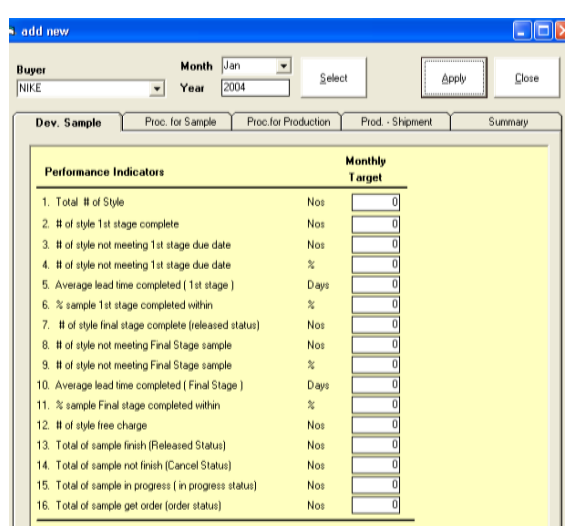

Gambar 24 Tampilan Konfigurasi - Target Bulanan

\section{J. Laporan Penelusuran}

- Pengembangan Sampel

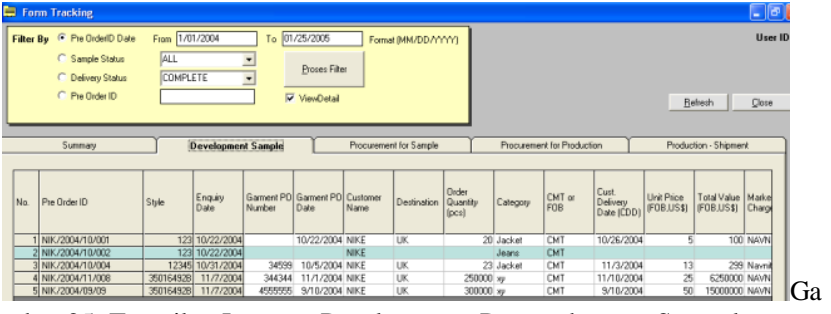

mbar 25. Tampilan Laporan Penelusuran - Pengembangan Sampel

- Pengadaan Barang Sampel

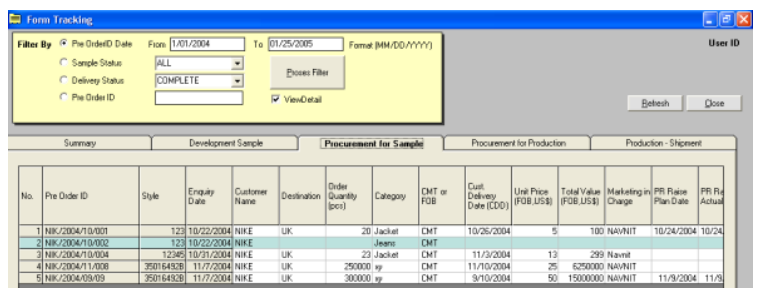

Gambar 26. Tampilan Laporan Penelusuran - Pengadaan Barang Sampel

\section{H. Pengadaan Barang Produksi}

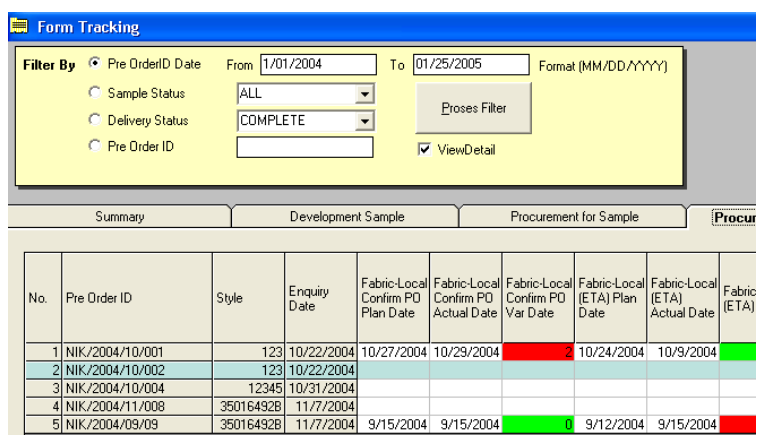

Gambar 27. Tampilan Laporan Penelusuran - Pengadaan Barang Produksi - Produksi-Pengapalan

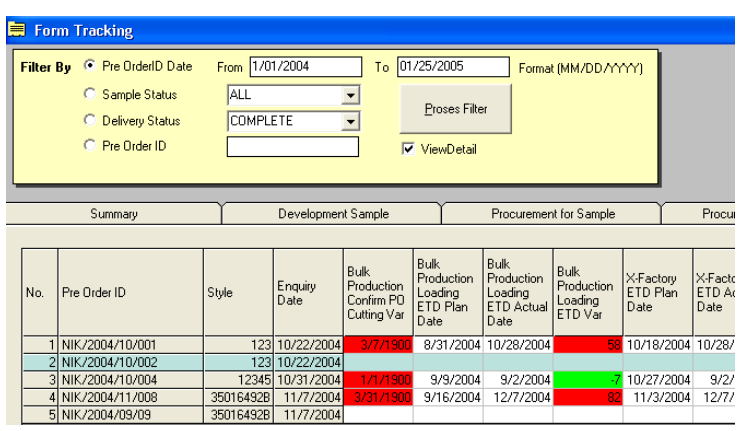

Gambar 28. Tampilan Laporan Penelusuran - Produksi-Pengapalan 


\section{K. Ringkasan}

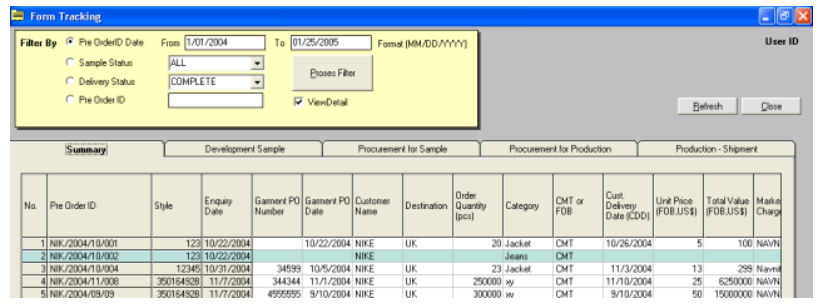

Gambar 29. Tampilan Laporan Penelusuran - Ringkasan

\section{Kartu Penilaian Kinerja}

- Pengembangan Sampel

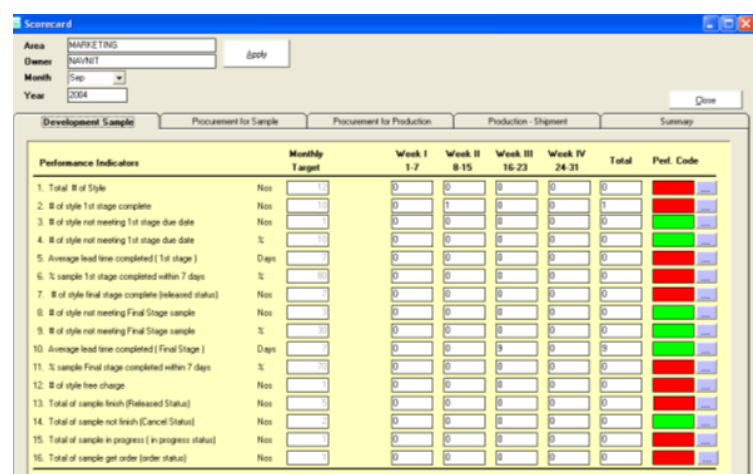

Gambar 30. Tampilan Kartu Penilaian Kinerja- Pengembangan Sampel

\section{Pengadaan Barang Sampel}

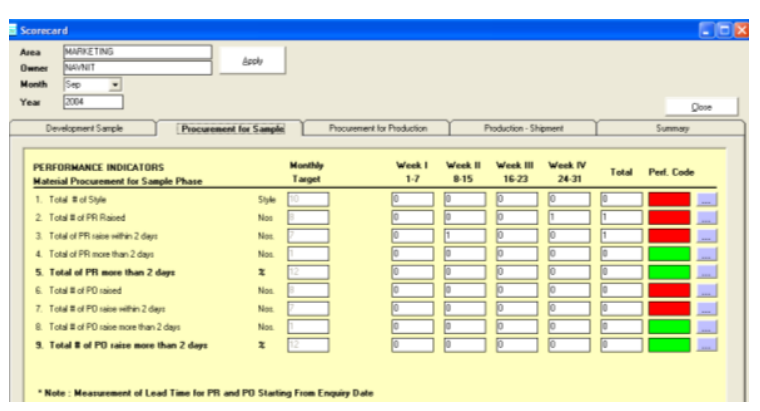

Gambar 31. Tampilan Kartu Penilaian Kinerja - Pengadaan Barang Sampel

\section{- $\quad$ Pengadaan Barang Produksi}

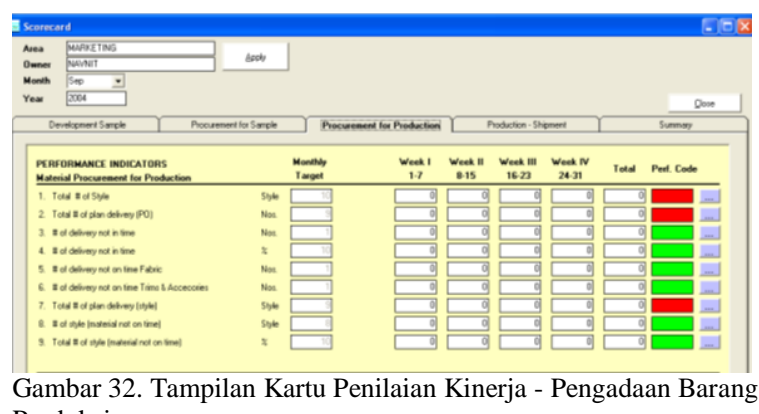
Produksi

\section{- Produksi-Pengapalan}

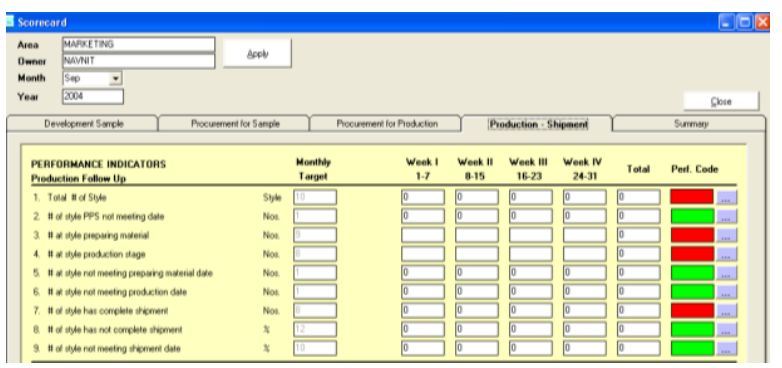

Gambar 34. Tampilan Kartu Penilaian Kinerja - Produksi-Pengapalan

- Ringkasan

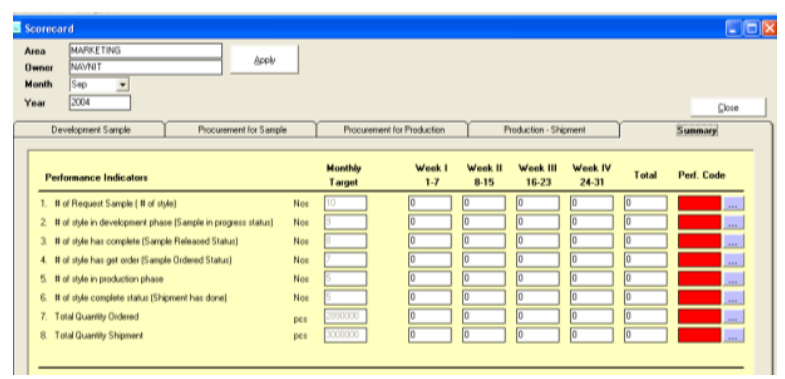

Gambar 35. Tampilan Kartu Penilaian

\section{Kesimpulan}

1. Dalam perancangan perangkat lunak ini telah dilakukan analisis dan perancangan prototip perangkat lunak simulasi sistem penerimaan dan penelusuran pesanan di divisi pemasaran industry garmen ekspor dan permodelan dilakukan dengan use case, dengan spesifikasi-spesifikasi sebagai berikut:

a. Adanya tampilan status masing-masing pemesanan pembeli, tahapan-tahapannya, dan kemungkinan perubahannya.

b. Menyajikan proses bisnis untuk penjualan dan pemesanan pemasukan data di divisi pemasaran

c. Adanya aspek untuk melakukan penelusuran terhadap pemesanan barang disertai dengan peringatan berupa pengaturan warna sebagai dasar pengambilan keputusan pihak manajemen

d. Kemampuan untuk melakukan konfigurasi lead time untuk tiap jenis pesanan menjadi lebih fleksibel dan khusus.

e. Keluaran perangkat lunak ini berupa Laporan Penelusuran dan Kartu Penilaian Kinerja dalam bentuk yang mirip spreadsheet. 
f. Adanya otorisasi dalam mengakses data dalam perangkat lunak ini.

2. Berdasarkan hasil pengujian yang dilakukan, prototip perangkat lunak ini telah memenuhi kriteria baik dari segi isi (sistem penerimaan pesanan di perusahaan garmen) maupun dari segi pemrograman (pembuatan perangkat Saran lunak), yaitu kode program.

Setelah melakukan pengujian terhadap perangkat lunak ini, masih ditemukan beberapa kekurangan dan keterbatasan dari perangkat lunak ini, sehingga untuk melengkapinya perlu dilakukan pengembangan penelitian lebih lanjut. Untuk itu beberapa saran sebagai bahan pertimbangan dan pengembangan penelitian selanjutnya adalah sebagai berikut:

1. Program ini belum bisa menampilkan tahapan program berdasarkan nama pembeli, karena banyaknya variasi antara pembeli, jenis, dan tahapan pengerjaannya dan data basenya belum tersedia, sehingga perlu pengembangan lebih lanjut untuk mengakomodir kebutuhan tersebut.

2. Pengujian terhadap aplikasi simulasi sistem penerimaan pesanan dilakukan melalui metode pengujian kotak hitam, yaitu berdasarkan speifikasi eksternal atau fungsi-fungsi yang dibutuhkan dalam sistem tanpa didasarkan pada pengetahuan tentang struktur kode dan logik internal, untuk memperoleh hasil pengetesan yang lebih optimal dapat digunakan metode pengujian kotak putih, yaitu pengujian dengan menyertakan pengetahuan tentang struktur kode dan logik internal.

\section{REFERENSI}

[1] Shepker, Matthew., "Teach Yourself Microsoft SQL Server 7 in 24 Hours", Sams, New York, 2000.

[2] Alam,J,Agus,M.,"Manajemen Database dengan Microsoft Visual Basic versi 6.0", Elex Media Komputindo., Bandung, 1999

[3] Muhammadi; Aminullah, Erman.; Soesilo, Budhi, "Analisis Sistem Dinamis, Lingkungan Hidup, Sosial, Ekonomi, Manajemen", UMJ Press, Jakarta, 2001

[4] Suhendar, A; Gunadi, Hariman., "Visual Modeling Menggunakan UML dan Rational Rose, Penerbit Informatika., Bandung, 2002.

[5] Eriksson, Hans-Erik and Penker, Magnus, UML Toolkit, Jhon Wiley \& Sons, Toronto, 1998.

[6] Roff,T.,Jason, "UML A beginner's Guide", McGraw-Hill/Osborne, New York, 2003.
[7] Prabowo, Anung, "Rancang Bangun Sistem Informasi Manajemen Untuk Manufakturing dilengkapi Monitoring Status Monitoring Status Projek dan Inventory Melalui WEB dan WAP", Prototip perangkat lunak , Jurusan Teknik Elektro, Fakultas Teknologi Industri, Institut Teknologi Bandung, 2003.

[8] Thalib, Abd, "Perancangan Sistem Informasi Barang Inventaris Berbasis WEB", Prototip perangkat lunak , Jurusan Teknik Elektro, Fakultas Teknologi Industri, Institut Teknologi Bandung, 2004.

[9] Sanusi, Adibrata, Edward, "Perancangan dan Implementasi Software Tool untuk Pengembangan Situs Kuliah Secara Elektronik", Prototip perangkat lunak , Jurusan Teknik Elektro, Fakultas Teknologi Industri, Institut Teknologi Bandung, 2003.

[10] Morari, Manfred, "Robust Process Control", Prentice Hall, 1989.

[11] Kakiay, Thomas J, "Pengantar Sistem Simulasi", ANDI., Yogyakarta, 2004. 